\title{
Ethnomedicine Knowledge of Iranian Traditional Healers and the Novel Coronavirus Disease 2019 (COVID-19)
}

\author{
Maryam Azimi ${ }^{1,2}$ D, Morteza Mojahedi ${ }^{3}$ (D), Roshanak Mokaberinejad ${ }^{4}$ (D), \\ Fatemeh Sadat Hasheminasab $^{5^{*} \text { if }}$
}

1. Gastroenterology and Hepatology Research Center, Kerman University of Medical Sciences, Kerman, Iran

2. Dept. of Traditional Medicine, School of Persian Medicine, Kerman University of Medical Sciences, Kerman, Iran

3. Traditional Medicine and History of Medical Sciences Research Center, Health Research Institute, Babol University of Medical Sciences, Babol, Iran

4. Dept. of Traditional Medicine, School of Traditional Medicine, Shahid Beheshti University of Medical Sciences, Tehran, Iran

5. Pharmacology Research Center, Zahedan University of Medical Sciences, Zahedan, Iran

\begin{tabular}{|c|}
\hline Article Info \\
\hline doil $10.30699 /$ jambs.29.135.238 \\
\hline $\begin{array}{c}\text { Received: 2020/09/07; } \\
\text { Accepted: 2021/01/19; } \\
\text { Published Online: } 28 \text { Feb 2021; }\end{array}$ \\
\hline $\begin{array}{l}\text { Use your device to scan and read the } \\
\text { article online }\end{array}$ \\
\hline 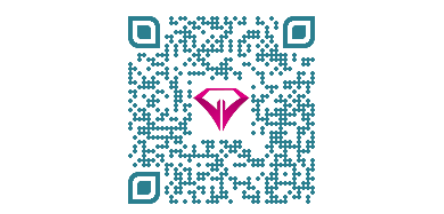 \\
\hline
\end{tabular}

Corresponding Information: Fatemeh Sadat Hasheminasab, Pharmacology Research Center, Zahedan University of Medica Sciences, Zahedan, Iran

E-Mail: : hashemifa67@gmail.com hasheminasab@zaums.ac.ir

\section{ABSTRACT}

Background \& Objective: In December 2019, the outbreak of coronavirus disease 2019 (COVID-19) was observed in China, and it it spread rapidly throughout the world. Iranian traditional healers have applied different medicinal plants to prevent and treat COVID-19 based on their ethnopharmacological knowledge. This research aimed to investigate the ethnomedicinal knowledge of Iranian traditional healers to alleviate COVID-19 signs and symptoms.

Materials \& Methods: Due to the limitations caused by COVID-19 pandemic, oral interviews were conducted by 26 traditional healers in Kerman and Zahedan cities in Iran. The names of recommended remedies for COVID-19 were collected, and their scientific names were authenticated. Next, a comprehensive research was carried out in the scientific databases. Finally, the herbs with any related proved properties to the respiratory system were listed; these herbs were probably useful for the COVID-19 prevention or treatment.

Results: Zataria multiflora, Althaea officinalis, Hordeum vulgare, Malva sylvestris, Matricaria chamomilla, Glycyrrhiza glabra, Allium sativum and Zingiber officinale are considered as the most popular herbs by Iranian traditional healers for prevention and/or treatment of COVID-19. Recent studies have demonstrated that the abovementioned herbs can be considered as good sources for alleviating the respiratory disorders such as influenza. Moreover, they have antitussive and immune-modulatory properties.

Conclusion: Since there is no effective treatment for COVID-19, the capacity of different traditional medicine and ethnomedicine knowledge can be used as good sources for new drug discovery after accurate studies.

Keywords: Iran, Ethnomedicine, Coronavirus, Pneumonia, Complementary therapies

\section{Introduction}

The outbreak of novel coronavirus disease 2019 (COVID-19) was first reported in Wuhan city, Hubei province in December 2019. It spread rapidly all over China and then almost throughout the world causing a global concern as a pandemic (1). The infection caused by COVID-19 has a wide range of severity, from asymptomatic disease to mild upper respiratory tract disease; it may also lead to severe pneumonia and even death (2). According to the different guidelines for managing COVID-19 pneumonia, patients with severe disease and respiratory distress always need hospitalization; other patients who develop mild to moderate symptoms (in the absence of any risk factors) are considered as outpatients who should be isolated at home and receive medication there (3).

This pandemic makes physicians with various therapeutic approaches (including herbal medicine, classic medicine, Chinese medicine, acupuncture, Persian medicine, etc.) to discover a way to cure this contagious infection or lessen its signs and symptoms (4). Exploring the registered clinical trials in primary registries of the World Health Organization (WHO) showed a large attention to complementary and alternative medicine (CAM) for managing the COVID-19 (4). Previously, 
notable trials had been conducted in the field of CAM for prevention, treatment, and rehabilitation of influenza and severe acute respiratory syndrome (SARS) (5).

Recent studies demonstrated that there is a tendency to apply CAM in various societies (6). The use of herbal remedies to prevent or treat infectious respiratory diseases is very common in Iran (7), and there is a tendency among people, even of different ethnic origins, to take the advantages of natural remedies to prevent the COVID-19 infection.

Despite significant differences between COVID-19 and common cold or influenza, there are some similarities in terms of clinical manifestations including cough, fever, fatigue, and myalgia (8). These similarities lead to experimented remedies prescription to control the COVID-19 infection. In different parts of the world, people tend to employ natural products and herbal medicine, either alone or as an alternative medicine, to relieve the signs and symptoms of the infection; this indicates the necessity of research for scientific documents of the applied medicinal plants (9).

This study was conducted to introduce the common herbs among Iranian traditional healers for preventing or treating COVID-19, as well as their efficacy, safety, and relative properties based on scientific databases.

\section{Materials and Methods}

This study was conducted in accordance with the guidelines of the Ethics Committee of Babol University of Medical Sciences, Iran (code: IR.MUBABOL.REC.1399.314).

Due to the specific conditions caused by the pandemic, such as social distancing, the closure of most places and shops, and the lack of direct access to traditional healers, oral interviews were conducted through telephone calls.

In the first step, 58 herbal shops were identified in two cities, including Zahedan $(n=30)$ and Kerman $(n=28)$. Attempts were made to find the contact information in various ways (via checking the phone numbers on their shop windows or inquiring from the nearby open shops). Finally, the contact information of 37 traditional healers were obtained. Among these, we did not succeed in contacting 4 healers; in addition, 7 healers were not willing to participate in the study. The aims and protocols of the project were explained to the 26 remaining traditional healers via making phone calls, and they were requested to offer their information to the researchers. Finally, the ethnopharmacology information of the studied traditional healers was recorded. In this regard, the names of the herbs introduced as remedies for preventing or alleviating the signs and symptoms of COVID-19 and other related data were collected. The data were collected by the local researchers who were familiar with the traditional names of each herb, as well as with the names under the medicinal plants in the herbal shops. Then, the introduced herbs were authenticated using botanical textbooks, and their scientific names were obtained (10).

In the next step, searching was conducted throughout the scientific databases including PubMed, Scopus, and Web of Sciences. The scientific names of all herbs along with keywords including "cough", "antitussive", "common cold", "influenza", "SARS", "immune response", "immunity" and "respiratory distress" were searched within "title and abstract" sections of the PubMed; "title, abstract, and keywords" sections of Scopus; and "title" section of Web of Sciences databases. Finally, the herbs documented in the above-mentioned fields were listed.

\section{Results}

Nowadays, different remedies are introduced by traditional healers and being used by Iranian people for prevention and treatment of respiratory diseases, such as influenza, common cold, and even COVID-19. In fact, many people desire to generalize their experiences of diseases like common cold and influenza into a new disease, like COVID-19. The herbs which are applied by Iranian traditional healers for preventing or curing the respiratory infections have been presented in Table 1.

Aerial parts of $Z$. multiflora and M. chamomilla, flowers of $A$. officinalis and $M$. sylvestris, seeds of $H$. vulgare, roots of $G$. glabra, rhizome of $Z$. officinale, and bulbs of $A$. Sativum are plant parts which are introduced by traditional healers. Remedies are utilized either separately or in combination with one other. All the introduced herbs except $A$. sativum and $H$. vulgare are usually used in the form of aqueous extract. Individuals mostly prefer to take advantages of $A$. sativum either as a raw fruit or macerated in vinegar, and $H$. vulgare in combination was with different vegetables as a soup . 
Table 1. Herbs applied by Iranian traditional healers to treat COVID-19 and some of their related properties according to the scientific documents.

\begin{tabular}{ccccc}
$\begin{array}{c}\text { Plant part } \\
\text { preparation }\end{array}$ & Study design & $\begin{array}{c}\text { Main related } \\
\text { outcome }\end{array}$ & Side effect & Ref. \\
\hline
\end{tabular}

\begin{tabular}{|c|c|c|c|c|c|c|}
\hline \multirow{5}{*}{ Z. multiflora } & \multirow{5}{*}{$\begin{array}{l}\text { Avishan- } \\
\text { Shirazi }\end{array}$} & $\begin{array}{l}\text { Carvacrol } \\
\text { (flavonoid) }\end{array}$ & $\begin{array}{l}\text { In vitro study } \\
\text { Relaxant effects on guinea } \\
\text { pig tracheal chains }\end{array}$ & Antitussive activity & $\begin{array}{c}\text { Not } \\
\text { mentioned }\end{array}$ & (11) \\
\hline & & $\begin{array}{c}\text { Dry extracts of } \\
\text { thyme herb and } \\
\text { primrose root }\end{array}$ & $\begin{array}{l}\text { Prospective, double-blind, } \\
\text { placebo-controlled clinical } \\
\text { trial } \\
\text { Evaluation the effects on } \\
\text { adults suffering from acute } \\
\text { bronchitis with productive } \\
\text { cough }\end{array}$ & $\begin{array}{l}\text { Effective on acute } \\
\text { bronchitis with } \\
\text { productive cough }\end{array}$ & $\begin{array}{l}\text { Severe or } \\
\text { serious } \\
\text { adverse } \\
\text { effects have } \\
\text { not been } \\
\text { reported }\end{array}$ & $(12)$ \\
\hline & & Essence & $\begin{array}{l}\text { Animal study } \\
\text { Evaluating the effects on } \\
\text { innate immunity }\end{array}$ & Enhancing immunity & $\begin{array}{c}\text { Not } \\
\text { mentioned }\end{array}$ & (13) \\
\hline & & Essential oil & $\begin{array}{l}\text { Animal study } \\
\text { Evaluation the effects on } \\
\text { replication rate of avian } \\
\text { influenza virus (H9N2 } \\
\text { subtype) in challenged } \\
\text { broiler chicks }\end{array}$ & $\begin{array}{c}\text { Anti-Influenza virus } \\
\text { activity }\end{array}$ & $\begin{array}{c}\text { Not } \\
\text { mentioned }\end{array}$ & (14) \\
\hline & & Extract & $\begin{array}{l}\text { Double-blinded randomized } \\
\text { clinical trial } \\
\text { Comparison of the herbal } \\
\text { syrup and diphenhydramine } \\
\text { in the treatment of common } \\
\text { cold-induced cough in } \\
\text { children }\end{array}$ & $\begin{array}{l}\text { Effective on common } \\
\text { cold }\end{array}$ & $\begin{array}{l}\text { No side } \\
\text { effects }\end{array}$ & $(15)$ \\
\hline \multirow{2}{*}{ A. officinalis } & \multirow{2}{*}{ Khatmi } & $\begin{array}{l}\text { Complex extract } \\
\text { and the } \\
\text { polysaccharide }\end{array}$ & $\begin{array}{c}\text { Animal study (cat) } \\
\text { Investigating the effects on } \\
\text { cough caused by } \\
\text { mechanical stimulation with } \\
\text { nylon fiber }\end{array}$ & Antitussive activity & $\begin{array}{c}\text { Not } \\
\text { mentioned }\end{array}$ & $(16)$ \\
\hline & & polysaccharides & $\begin{array}{l}\text { In vitro study } \\
\text { Evaluating the anti- } \\
\text { complementary activity of } \\
\text { polysaccharides on human } \\
\text { serum }\end{array}$ & $\begin{array}{l}\text { Immunomodulatory } \\
\text { effect }\end{array}$ & $\begin{array}{c}\text { Not } \\
\text { mentioned }\end{array}$ & $(17)$ \\
\hline \multirow{2}{*}{ H. vulgare } & \multirow{2}{*}{ Jow } & Aqueous extract & $\begin{array}{l}\text { Randomized controlled trial } \\
\text { Evaluating the effects of a } \\
\text { novel barley-based } \\
\text { formulation on allergic } \\
\text { rhinitis }\end{array}$ & $\begin{array}{l}\text { Effective on sneezing, } \\
\text { runny nose, itchy } \\
\text { nose, post nasal } \\
\text { discharge }\end{array}$ & $\begin{array}{c}\text { Not } \\
\text { mentioned }\end{array}$ & (18) \\
\hline & & Aqueous extract & $\begin{array}{c}\text { In vivo study } \\
\text { Evaluating the activity } \\
\text { against influenza viruses } \\
\text { H1N1 ‘H3N2 ‘B }\end{array}$ & $\begin{array}{c}\text { Anti-Influenza virus } \\
\text { activity }\end{array}$ & $\begin{array}{c}\text { Not } \\
\text { mentioned }\end{array}$ & (19) \\
\hline M. sylvestris & Panirak & Extract & $\begin{array}{l}\text { Animal study (common } \\
\text { carp) } \\
\text { Evaluating the effects on } \\
\text { growth performance, } \\
\text { digestive enzyme activities, } \\
\text { and immune responses }\end{array}$ & $\begin{array}{l}\text { Enhancing innate } \\
\text { immunity }\end{array}$ & $\begin{array}{c}\text { Not } \\
\text { mentioned }\end{array}$ & $(20)$ \\
\hline
\end{tabular}




\begin{tabular}{|c|c|c|c|c|c|c|}
\hline & & $\begin{array}{l}\text { Plant part } \\
\text { preparation }\end{array}$ & Study design & $\begin{array}{l}\text { Main related } \\
\text { outcome }\end{array}$ & Side effect & Ref. \\
\hline \multirow{2}{*}{$\begin{array}{c}\text { M. } \\
\text { chamomilla }\end{array}$} & \multirow{2}{*}{ Babooneh } & $\begin{array}{l}\text { Hyaluronic acid, } \\
\text { N-acetylcysteine } \\
\text { and chamomile } \\
\text { aerosolized }\end{array}$ & $\begin{array}{l}\text { Clinical trial } \\
\text { Evaluation the effects on } \\
\text { chronic cough of COPD } \\
\text { patients }\end{array}$ & $\begin{array}{l}\text { Antitussive activity } \\
\text { increasing quality of } \\
\text { life in COPD patients }\end{array}$ & $\begin{array}{c}\text { Not } \\
\text { mentioned }\end{array}$ & $(21)$ \\
\hline & & $\begin{array}{l}\text { As a part of a } \\
\text { herbal water- } \\
\quad \text { extract }\end{array}$ & $\begin{array}{l}\text { Clinical trial } \\
\text { Evaluating th effects on } \\
\text { histamine release from mast } \\
\text { cells and on allergic asthma }\end{array}$ & $\begin{array}{l}\text { Decreasing histamine } \\
\text { secretion from mast } \\
\text { cells } \\
\text { Antitussive activity }\end{array}$ & $\begin{array}{c}\text { Not } \\
\text { mentioned }\end{array}$ & $(22)$ \\
\hline \multirow{4}{*}{ G. glabra } & \multirow{4}{*}{ Shirin-Bayan } & $\begin{array}{l}\text { An active } \\
\text { component of } \\
\text { liquorice root }\end{array}$ & $\begin{array}{l}\text { In vitro study } \\
\text { Evaluating the effects on } \\
\text { replication of SARS- } \\
\text { associated coronavirus }\end{array}$ & $\begin{array}{l}\text { Anti SARS-associated } \\
\text { coronavirus activity }\end{array}$ & $\begin{array}{c}\text { Not } \\
\text { mentioned }\end{array}$ & $(23)$ \\
\hline & & $\begin{array}{l}\text { Water-soluble } \beta \text { - } \\
\text { cyclodextrin- } \\
\text { glycyrrhetinic } \\
\text { acid }\end{array}$ & $\begin{array}{c}\text { In vitro study } \\
\text { Investigation of the } \\
\text { cytopathic effect against } \\
\text { influenza H1N1 }\end{array}$ & $\begin{array}{l}\text { Anti-Influenza virus } \\
\text { activity }\end{array}$ & $\begin{array}{c}\text { Not } \\
\text { mentioned }\end{array}$ & (24) \\
\hline & & $\begin{array}{l}\text { As a part of a } \\
\text { traditional } \\
\text { preparation }\end{array}$ & $\begin{array}{c}\text { Randomized, double- } \\
\text { blinded, placebo-controlled } \\
\text { clinical trial } \\
\text { Evaluating the effects on } \\
\text { the treatment of chronic } \\
\text { cough }\end{array}$ & Antitussive activity & $\begin{array}{c}\text { Not } \\
\text { mentioned }\end{array}$ & $(25)$ \\
\hline & & $\begin{array}{l}\text { Aqueous } \\
\text { methanolic } \\
\text { extract }\end{array}$ & $\begin{array}{c}\text { In vivo study } \\
\text { Evaluating the cell } \\
\text { mediated immune response } \\
\text { via different tests }\end{array}$ & $\begin{array}{c}\text { Immunomodulatory } \\
\text { effect }\end{array}$ & $\begin{array}{c}\text { Not } \\
\text { mentioned }\end{array}$ & (26) \\
\hline \multirow[t]{2}{*}{ S. ativum } & \multirow{2}{*}{ Seer } & Extract & $\begin{array}{c}\text { In vitro study } \\
\text { Investigation of the effects } \\
\text { on influenza } B \text {, herpes } \\
\text { simplex and coxsackie } \\
\text { viruses }\end{array}$ & $\begin{array}{l}\text { Anti-Influenza virus } \\
\text { activity }\end{array}$ & $\begin{array}{c}\text { Not } \\
\text { mentioned }\end{array}$ & $(27)$ \\
\hline & & Extract & $\begin{array}{l}\text { Animal study (fish) } \\
\text { Evaluating the effects of } \\
\text { supplemented diet on the } \\
\text { lysozyme activity in the } \\
\text { skin mucus }\end{array}$ & $\begin{array}{l}\text { Strengthening the } \\
\text { non-specific } \\
\text { immunity }\end{array}$ & $\begin{array}{c}\text { Not } \\
\text { mentioned }\end{array}$ & $(28)$ \\
\hline \multirow{3}{*}{ Z. officinale } & \multirow{3}{*}{ Zanjabeel } & $\begin{array}{l}\text { Water extracted } \\
\text { polysaccharides }\end{array}$ & $\begin{array}{l}\text { Animal study (Guinea pigs) } \\
\text { Investigating the efficacy } \\
\text { against citric acid-induced } \\
\text { cough }\end{array}$ & Antitussive activity & $\begin{array}{l}\text { Not } \\
\text { mentioned }\end{array}$ & (29) \\
\hline & & Aqueous extract & $\begin{array}{c}\text { In vitro study } \\
\text { Evaluating the inhibitory } \\
\text { activity against influenza } \\
\text { virus type A by means of a } \\
\text { modified hemagglutination } \\
\text { inhibition test }\end{array}$ & $\begin{array}{l}\text { Anti-Influenza virus } \\
\text { activity }\end{array}$ & $\begin{array}{l}\text { Not } \\
\text { mentioned }\end{array}$ & $(30)$ \\
\hline & & Essential oil & $\begin{array}{c}\text { Animal study (fish) } \\
\text { Evaluating some } \\
\text { hematological and immune } \\
\text { parameters }\end{array}$ & $\begin{array}{l}\text { Strengthening the } \\
\text { non-specific } \\
\text { immunity }\end{array}$ & $\begin{array}{c}\text { Not } \\
\text { mentioned }\end{array}$ & $(31)$ \\
\hline
\end{tabular}




\section{Discussion}

COVID-19 has deeply affected different countries via influencing the public health and inducing health service costs (32). The control of contagious respiratory infection can be classified into three levels, including a) prevention, b) treatment and decreasing the clinical signs and symptoms, and c) rehabilitation of the disease $(5,9)$. According to the recent studies, herbal medicine and traditional Chinese medicine (TCM) have played an important role in controlling previous infectious diseases, including SARS and Middle Eastern Respiratory Syndrome (MERS). These experiences have led to extensively employ TCM for the treatment of COVID-19 $(5,9)$.

According to the history of medicine, pneumonia has been discussed in the Persian medicine. Persian medicine, which is based on Mizaj (temperament) and humoral theory, has been one of the popular medical schools during the medieval times. The flourishing of this medical school is due to the dedication of the experiences and knowledge of the ancient Persian physicians and scholars $(33,34)$. According to Persianmedicine manuscripts, the term "Dhat al-Ri' $a$ " is used to denote the lung inflammation with fever due to infection and as pneumonia; the term "Hawa'-i-wabai" is applied for describing the epidemy of hightransmitted infections and the outbreak of contagious diseases. From the earliest times, Iranian physicians entitled the epidemic of respiratory infections as "nazla'-i-wabai" (35).

Persian physicians suggested very useful, intelligent, and wise recommendations for controlling and preventing the contagious epidemic diseases; they especially emphasized hygiene observance. Persian medicine has referred to the issue of "quarantine". It means that people should stay at home as much as possible to end the infectious epidemics; if they have to be in the community, they should put a handkerchief soaked in vinegar, onion, and garlic in front of one's mouth and nose (as a mask) and return home as soon as possible. On the other hand, according to the Persian medicine, if the environmental pollution is high, it is better to close the doors and windows of the houses and disinfect the air inside the house with methods such as spraying vinegar and rose water, putting onions, and/or boiling or burning some special plants (35). Recent studies have reported the antiseptic properties of some agents, such as harmel (Peganum harmala) (36). In case of mild environmental pollution, it is recommended to open the doors and windows to perform proper ventilation (35).

It is noteworthy that the ethnopharmacology knowledge, which is currently common among Iranian people, is a different and separate notion from Persian medicine; nevertheless, Iranian folklore medicine and their ethnopharmacology knowledge are considerably influenced by Persian medicine. Although the Persian medicine replacement with classic one has occurred in academia in Iran since the nineteenth century, the application of the natural remedies is still very common in Iran.

Traditionally, Iranian people refer to the local herbal stores and obtain appropriate natural remedies; and the healers guide the health seekers. Traditional healers mostly gain their traditional medicine knowledge from their past generation (37). The use of herbs for treating various diseases has been mingled with Iranian culture. A cross-sectional study showed that $54 \%$ of patients with diabetes mellitus who live in Kashan, Iran used at least one herb for controlling their blood sugar (38). Another study in Qom, Iran demonstrated that $78 \%$ of parents reported the use of traditional methods for reducing neonatal jaundice (39).

The most common medicinal plants used in Iran for preventing or alleviating the COVID-19 signs and symptoms and their proved properties are listed in Table 1. The listed herbs can be considered as good sources for alleviating the respiratory disorders. Some attributes such as antitussive, anti-influenza virus, immune-modulatory, enhancing innate immunity, and anti-SARS-associated coronavirus property are remarkable. However, further accurate studies are needed to evaluate their possible effects on preventing and treating COVID-19 infection.

This study was conducted to assess the scientific evidence of herbal medicines used to prevent and control the complications of COVID-19 in Iran. It is noteworthy that in the written sources of Persian medicine, there are considerable recommendations for the prevention and treatment of acute respiratory diseases; however, this is outside the scope of this survey and requires a separate study.

\section{Conclusion}

There is no proved effective way for preventing or treating the COVID-19. Iranian traditional healers prescribe different herbs to prevent and/or treat this disease based on their ethnomedicine knowledge. Regarding the various medicinal properties of the herbs introduced above, more human studies are needed to assess their effects and safety on COVID-19.

\section{Funding Sources}

No funding sources.

\section{Conflict of Interest}

The authors declared no conflict of interest. 


\section{References}

1. Lai CC, Shih TP, Ko WC, Tang HJ, Hsueh P-R. Severe acute respiratory syndrome coronavirus 2 (SARS-CoV-2) and corona virus disease-2019 (COVID-19): the epidemic and the challenges. Int J Antimicrob Agents. 2020:105924. [DOI:10.1016/j.ijantimicag.2020.105924]

2. Huang C, Wang Y, Li X, Ren L, Zhao J, Hu Y, et al. Clinical features of patients infected with 2019 novel coronavirus in Wuhan, China. The Lancet. 2020;395(10223):497-506. [DOI:10.1016/S0140-6736(20)30183-5]

3. http://dme.behdasht.gov.ir/uploads/Dastoor_Ke shvari.pdf.

4. Qiu R, Wei X, Zhao M, et al. Outcome reporting from protocols of clinical trials of Coronavirus disease 2019 (COVID-19): a review. medRxiv. 2020. [DOI:10.1101/2020.03.04.20031401]

5. Luo H, Tang Q1, Shang Yx, et al. Can Chinese medicine be used for prevention of corona virus disease 2019 (COVID-19)? A review of historical classics, research evidence and current prevention programs. Chin J Integr Med. 2020:1-8. [DOI:10.1007/s11655-020-3192-6]

6. Fjær EL, Landet ER, McNamara CL, Eikemo TA. The use of complementary and alternative medicine (CAM) in Europe. BMC Complement Med Therap. 2020;20:1-9. [DOI:10.1186/s12906-020-02903-w]

7. Jalali A, Raesi Vanani A, Shirani M. Ethnobotanical approaches of traditional medicinal plants used in the management of asthma in Iran. Jundishapur J Nat Pharmaceut Product. 2020;15(1). $\quad$ e62269 [DOI:10.5812/ijnpp.62269]

8. $\mathrm{Zu} \mathrm{ZY,} \mathrm{Jiang} \mathrm{MD,} \mathrm{Xu} \mathrm{PP,} \mathrm{et} \mathrm{al.} \mathrm{Coronavirus}$ Disease 2019 (COVID-19): A Perspective from China. Radiology. 2020:200490. [DOI:10.1148/radiol.2020200490]

9. Cui HT, Li YT, Guo LY, et al. Traditional chinese medicine for treatment of coronavirus disease 2019: a review. Trad Med Res. 2020;5(2):65-73.

10. Ghamarian AR HM, Javadi M. Physicians Desk Refrence. Tehran: Clinical pharmacy Department, Tehran University of Medical Sciences; 2011-2012.

11. Boskabady M, Jandaghi P. Relaxant effects of carvacrol on guinea pig tracheal chains and its possible mechanisms. Die Pharmazie. 2003;58(9):661-3.

12. Kemmerich B. Evaluation of efficacy and tolerability of a fixed combination of dry extracts of thyme herb and primrose root in adults suffering from acute bronchitis with productive cough. Arzneimittelforschung. 2007;57(09):607-15. [DOI:10.1055/s-00311296656]

13. Shokri H, Asadi F, Bahonar AR, Khosravi AR. The role of Zataria multiflora essence (Iranian herb) on innate immunity of animal model. Iran J Immunol. 2006;3(4):164-8.

14. Shayeganmehr A, Vasfi Marandi M, Karimi V, Barin A, Ghalyanchilangeroudi A. Zataria multiflora essential oil reduces replication rate of avian influenza virus (H9N2 subtype) in challenged broiler chicks. $\mathrm{Br}$ Poult Sci. 2018;59(4):389-95.

\section{[DOI:10.1080/00071668.2018.1478064]}

15. Hosseini F, Mahjoub H, Amanati A, Fazlian MM, Sedighi I. Comparison of zataria multiflora extract syrup and diphenhydramine in the treatment of common cold-induced cough in children: A double-blind, randomized, clinical trial. Arch Pediatr Infect Dis. 2016;4(3). [DOI:10.5812/pedinfect.35495]

16. Nosal'ova G, Strapkova A, Kardosova A, Capek P, Zathurecký L, Bukovská E. Antitussive action of extracts and polysaccharides of marsh mallow (Althea officinalis L., var. robusta). Die Pharmazie. 1992;47(3):224-6.

17. Yamada H, Nagai T, Cyong JC, et al. Relationship between chemical structure and anti-complementary activity of plant polysaccharides. Carbohydr Res. 1985;144(1):101-11. [DOI:10.1016/00086215(85)85011-4]

18. Derakhshan A, Khodadoost M, Ghanei M, et al. Effects of a novel barley-based formulation on allergic rhinitis: A randomized controlled trial. Endocr Metab Immune Disord Drug Targets. 2019;19(8):1224-31. [DOI:10.2174/1871530319666190306100611]

19. Nagai E, Iwai M, Koketsu $R$, et al. Antiinfluenza virus activity of Adlay Tea Components. Plant Foods Hum Nutr. 2019;74(4):538-43. [DOI:10.1007/s11130-01900773-3]

20. Bilen S, Filogh AMO, Ali AB, Kenanoğlu ON, Zoral MA. Effect of common mallow (Malva sylvestris) dietary supplementation on growth performance, digestive enzyme activities, haemotological and immune responses of common carp (Cyprinus carpio). Aquaculture Int. 2020;28(1):73-84. [DOI:10.1007/s10499019-00444-9]

21. Cesaro C, Cautiero T, Cautiero V, et al. Therapeutic efficacy of hyaluronic acid, Nacetylcysteine and chamomile aerosolized in 
chronic cough of COPD patients (GOLD stage III-IV). Minerva Pneumol. 2014;53(1):15-20.

22. Haggag EG, Abou-Moustafa MA, Boucher W, Theoharides TC. The effect of a herbal waterextract on histamine release from mast cells and on allergic asthma. J Herb Pharmacother. 2003;3(4):41-54

[DOI:10.1080/J157v03n04 03]

23. Cinatl J, Morgenstern B, Bauer G, Chandra P, Rabenau H, Doerr H. Glycyrrhizin, an active component of liquorice roots, and replication of SARS-associated coronavirus. The Lancet. 2003;361(9374):2045-6. [DOI:10.1016/S01406736(03)13615-X]

24. Liang S, Li M, Yu X, et al. Synthesis and structure-activity relationship studies of watersoluble $\quad \beta$-cyclodextrin-glycyrrhetinic acid conjugates as potential anti-influenza virus agents. Eur J Med Chem. 2019;166:328-38. [DOI:10.1016/j.ejmech.2019.01.074]

25. Ghaemi H, Masoompour SM, Afsharypuor S, et al. The effectiveness of a traditional Persian medicine preparation in the treatment of chronic cough: A randomized, double-blinded, placebocontrolled clinical trial. Complement Ther Med. 2020;49. [DOI:10.1016/j.ctim.2020.102324]

26. Hussain K, Iqbal Z, Abbas RZ, Khan MK, Saleemi MK. Immunomodulatory activity of Glycyrrhiza glabra extract against mixed Eimeria infection in chickens. Int $\mathrm{J}$ Agric Biol. 2017;19(4):928-32.

[DOI:10.17957/IJAB/15.0397]

27. Tsai Y, Cole LL, Davis LE, Lockwood SJ, Simmons V, Wild GC. Antiviral properties of garlic: in vitro effects on influenza $\mathrm{B}$, herpes simplex and coxsackie viruses. Planta Med. 1985;51(05):460-1. [DOI:10.1055/s-2007969553]

28. Ahmadniaye Motlagh H, Safari O, Selahvarzi Y, Baghalian A, Kia E. Non-specific immunity promotion in response to garlic extract supplemented diets in female Guppy (Poecilia reticulata). Fish Shellfish Immunol. 2020;97:969. [DOI:10.1016/j.fsi.2019.12.007]

29. Bera K, Nosalova G, Sivova V, Ray B. Structural elements and cough suppressing activity of polysaccharides from Zingiber officinale rhizome. Phytother Res. 2016;30(1):105-11. [DOI:10.1002/ptr.5508]
30. Park KJ, Lee HH. In vitro antiviral activity of aqueous extracts from Korean medicinal plants against influenza virus type A. J Microbiol Biotechnol. 2005;15(5):924-9.

31. Fadeifard F, Raissy M, Jafarian M, Boroujeni HR, Rahimi M, Faghani M. Effects of black seed (Nigella sativa), ginger (Zingiber officinale) and cone flower (Echinacea angustifolia) on the immune system of rainbow trout, Oncorhynchus mykiss. Arq Bras Med Vet Zootec. 2018;70(1):199-204. [DOI:10.1590/1678-4162-8489]

32. Wang Z, Li L, Yan J, Yao Y. Evaluating the traditional chinese medicine (TCM) officially recommended in China for COVID-19 using ontology-based side-effect prediction framework (OSPF) and deep learning. Preprints .2020 . 2020020230 [DOI:10.20944/preprints202002.0230.v1]

33. Hasheminasab F, Sharififar F, Hashemi S, Setayesh M. An evidence-based research on botanical sources for oral mucositis treatment in traditional persian medicine. Curr Drug Discov Technol. 2020. [DOI:10.2174/1570163817666200203110803]

34. Hasheminasab FS, Tajadini H, Setayesh M. An evidence-based study on pharmacological treatments of non-alcoholic fatty liver disease based on traditional persian medicine. Curr Tradit Med. 2020;6(3):188-202. [DOI:10.2174/2215083805666190902114137]

35. Avicenna H. The canon of medicine (Al-Qanon fi al-Tibb). Beirut, Lebanon: Dar Ihyaa alTuraath al-Arabi. 2005.

36. Al-Shamma A, Drake S, Flynn D, et al. Antimicrobial agents from higher plants. Antimicrobial agents from Peganum harmala seeds. J Nat Prod (Gorakhpur). 1981;44(6):7457. [DOI:10.1021/np50018a025]

37. Hooper D, McNair JB, Field H. Useful plants and drugs of Iran and Iraq: Fieldiana Life Earth. Chicago,1937.

38. Azizi-Fini I, Adib-Hajbaghery M, Gharehboghlou Z. Herbal medicine use among patients with type 2 diabetes in Kashan, Iran, 2015. Eur J Integr Med. 2016;8(4):570-5. [DOI:10.1016/j.eujim.2016.04.003]

39. Heydari M, Heydari H, Saadati A, Gharehbeglou M, Tafaroji J, Akbari A. Ethnomedicine for neonatal jaundice: A crosssectional survey in Qom, Iran. J Ethnopharmacol. 2016;193:637-42. [DOI:10.1016/j.jep.2016.10.019] 


\section{How to Cite This Article:}

Azimi M, Mojahedi M, Mokaberinejad R, Hasheminasab F S. Ethnomedicine Knowledge of Iranian Traditional Healers and the Novel Coronavirus Disease 2019 (COVID-19). J Adv Med Biomed Res. 2021; 29 (135) :238245.

\section{Download citation:}

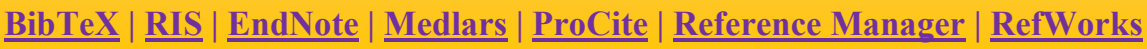

\section{Send citation to:}

(3) Mendeley Zotero (2) RefWorks RefWorks 